\title{
Influence of environmental enrichment on the behavior of captive Ateles paniscus (Primates: Atelidae) in the Parque Zoobotânico Getúlio Vargas, Salvador, Bahia, Brazil
}

\author{
Denise Costa Rebouças Lauton ${ }^{1 *}$ \\ Airan dos Santos Protázio ${ }^{2}$ \\ Jacileide Santos Silva Lima ${ }^{3}$ \\ Téo Veiga de Oliveira ${ }^{4}$

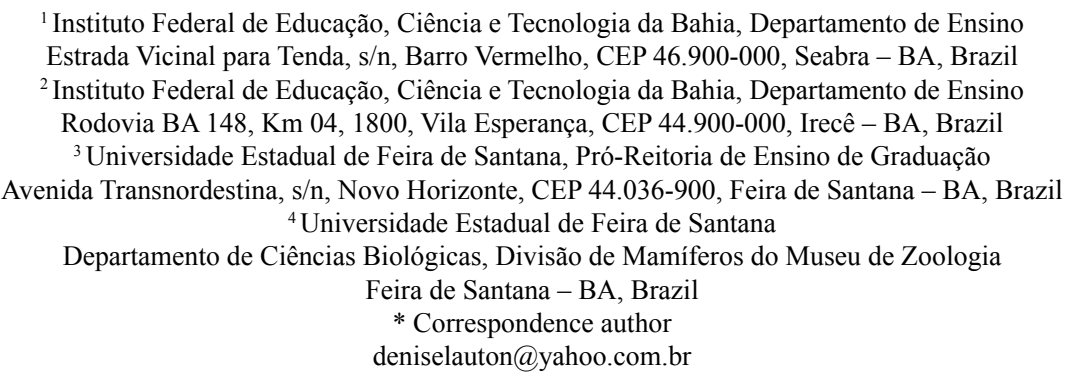

Submetido em 05/03/2020

Aceito para publicação em 15/08/2020

\section{Resumo}

Influência do enriquecimento ambiental sobre o comportamento de Ateles paniscus (Primates: Atelidae) mantido cativo no Parque Zoobotânico Getúlio Vargas, Salvador, Bahia, Brasil. Técnicas de enriquecimento ambiental tornam o ambiente cativo mais interessante e agradável para os animais, aumentando o bem-estar e prevenindo o desenvolvimento de comportamentos anormais. Nesta pesquisa, avaliamos a influência de diferentes técnicas de enriquecimento no comportamento de dois indivíduos de Ateles paniscus mantidos cativos no Parque Zoobotânico Getúlio Vargas, Salvador, Brasil. O estudo foi dividido em cinco fases: controle; enriquecimento sensorial; enriquecimento social; enriquecimento alimentar e pós-enriquecimento. O método animal-focal com registro instantâneo foi utilizado para registrar os atos comportamentais exibidos nas diferentes fases de enriquecimento e estes foram comparados, quanto à sua frequência, com os exibidos na fase controle. Também foi comparada a frequência de uso dos artefatos introduzidos no recinto durante as fases sensorial e alimentar. De modo geral, não houve diferenças entre os atos comportamentais exibidos nas diferentes fases de enriquecimento, exceto durante a fase de enriquecimento alimentar do macho. Também não houve diferenças quanto ao uso dos artefatos. Contudo, os resultados evidenciam a influência de um ambiente enriquecido sobre a frequência de ocorrência dos comportamentos dos indivíduos. É possível que as condições do recinto e a presença dos visitantes exerçam influências negativas no comportamento dos indivíduos, de modo a não favorecer a redução efetiva dos comportamentos anormais observado.

Palavras-chave: Bem-estar; Comportamento natural; Estereotipia; Macaco-aranha; Zoológico 


\section{Abstract}

Enrichment techniques make captive environments more interesting and pleasant for animals, aiding their welfare and preventing the development of abnormal behaviors. In this study, we evaluated the influence of distinct enrichment techniques on the behavior of two captive spider monkeys, Ateles paniscus, in the Parque Zoobotânico Getúlio Vargas, Salvador municipality, Brazil. The study was divided into five phases: control, sensory enrichment, social enrichment, feeding enrichment, and post-enrichment. We used the focal-animal sampling technique to record the individuals' behavior. We compared the frequency of the behavioral acts shown in the enrichment phases with those of the control phase. The frequency of manipulation of the object placed in the enclosure during the sensory and feeding phases was also compared. Overall, no significant changes were observed in the behavioral repertoire of individuals, except during the feeding enrichment phase of the male individual. There were also no significant differences in use of enrichment objects. However, the results showed the influence of an enriched environment on the frequency of the individuals' behavioral acts. Perhaps the enclosure conditions and the flow of visitors may have had some negative influence that did not allow for a more effective reduction in abnormal behaviors.

Key words: Natural behavior; Spider monkey; Stereotypy; Welfare; Zoo

\section{Introduction}

Captive environments are distinct from natural habitats, mainly due to spatial restriction and a lack of physical, cognitive, and social stimulation. This can lead to the development of a variety of abnormal behaviors in animals (BOERE, 2001; RANGELNEGRÍN et al., 2009; BUCHANAN-SMITH, 2010; MANACERO et al., 2014), such as aggressiveness, self-mutilation, stereotyped movements, lethargy, anxiety and depression (BOERE, 2001; LAUTON; COSTA NETO, 2018; LAUTON et al., 2019); which justify the need to monitor the welfare of individuals living in captive environments.

Although there is no consensus on the definition of 'animal welfare' (ETIM et al., 2013), it can refer to traits related to an individual's health, such as reproductive and growth rate, metabolism, activity patterns and mortality (BROOM, 1986; VOLPATO et al., 2009). Thus, understanding the connections among biological parameters, such as health and illness, distresses and stresses, as well as the effects of the environment on captive animals, is essential to better define animal welfare (BROOM, 1991; VOLPATO et al., 2009).

According to Broom (1986), welfare is the state of an individual in its relationship to the environment, which can be measured through the satisfaction (or not) of their needs. Based on this definition, we may consider that enrichment to satisfy natural needs is an effective way of improving the welfare of captive organisms. Enrichment consists of methods and procedures aimed to provide the animal with a more stimulating environment, and that leads to a more diverse behavioral repertoire (NEWBERRY, 1995; BOERE, 2001; SHEPHERDSON, 2010).

For primates, several enrichment techniques have been proposed according to their sex and age, social organization or taxonomic group of interest. In general, the five enrichment categories suggested by Bloomsmith et al. (1991) are most frequently applied to these organisms: social, physical, occupational (cognitive), sensory and nutritional. Each category has the potential to influence the activity patterns of captive individuals (BLOOMSMITH et al., 1991; BOERE, 2001; BUCHANAN-SMITH, 2010).

The use of environmental enrichment techniques has shown to be effective for captive animals (BOERE, 2001; RAMPIM; OLIVA, 2016; AZEVEDO; BARÇANTE, 2018). Enrichments can decrease abnormal behavior (CARLSTEAD; SHEPHERDSON, 1994; BOERE, 2001) and, increase species-typical behavior (BUCHANAN-SMITH, 2010; SHEPHERDSON, 2010; SOBROZA; FORTES, 2018). These effects have been used as parameters to measure the degree of welfare of animals found in captivity (JWGR, 2009; BUCHANANSMITH, 2010). 
Spider monkeys that live in captivity may show individualized responses to stress, such as abnormal activities or physiological changes. In Ateles marginatus individuals, Almeida et al. (2008) observed stereotyped movements that were associated with food supply. In Ateles geoffroyi yucatanensis individuals, RangelNegrín et al. (2009) identified high levels of corticoids from fragmented and captive environments; they hypothesized that these results may be conductors of metabolic and behavioral stress associated with human proximity. These findings demonstrate the need to verify the influence of different enrichment techniques on the behavior of captive spider monkeys to complement strategies aimed at enhancing their welfare.

The present study aims to evaluate the effects of different environmental enrichment techniques on the behavior of Ateles paniscus (Linnaeus, 1758) individuals kept in captivity at the Parque Zoobotânico Getúlio Vargas. We predict that different enrichment conditions will provide different behavioral responses, such as: (i) decreased stereotyped behavior; (ii) increased social or resting behavior, as well as other behaviors similar to those shown in the wild; and (iii) differences in the utilization of the artifacts used in sensory and feeding enrichment. This information was used as a parameter to assess the degree of welfare of captive individuals.

\section{Material and Methods}

\section{Study species}

The genus Ateles includes spider monkeys, which are some of the largest neotropical primates (CHAPMAN; CHAPMAN, 1990). They are widely distributed in Amazonia, from Brazil to central Bolivia, reaching southern Mexico (KELLOGG; GOLDMAN, 1944). Among the six valid species (PORTO et al., 2015), Ateles paniscus (spider monkey) is characterized by its dark pelage and naked face (KONSTANT et al., 1985). In nature, the animal is typically arboreal, using mainly the forest canopy (MITTERMEIER; VAN ROOSMALEN, 1981; VAN ROOSMALEN, 1985; YOULATOS, 2002). Its prehensile tail and very elongated limbs allow for climbing and brachiation (MITTERMEIER,
1978; YOULATOS, 2002). The genus is frugivore, but also eats leaves and flowers (MITTERMEIER; VAN ROOSMALEN, 1981; VAN ROOSMALEN, 1985).

Wild Ateles paniscus live in groups with approximately 20 individuals, which can be seen in subgroups during the day (MITTERMEIER; VAN ROOSMALEN, 1981; VAN ROOSMALEN, 1985). According to the International Union for Conservation of Nature - IUCN (2020), A. paniscus is classified as vulnerable; its wild population has been decreasing. Habitat destruction and hunting are the main threats to spider monkeys (see also VAN ROOSMALEN, 1985; TAKAHASHI, 2008). Recent projections suggest that Atelidae species may lose more than $40 \%$ of their natural habitat by 2050 (SOARES-FILHO et al., 2006), which would put the survival of these organisms at risk. This information highlights the importance of efforts aimed at the biology and ecology of A. paniscus in the natural environment and the relevance of initiatives to stimulate the welfare and survival of the captive individuals. Perhaps the knowledge generated may support future initiatives that promote the conservation of these organisms.

\section{Study area and study animals}

This research was conducted in the Parque Zoobotânico Getúlio Vargas (PZGV) (1301'S; $\left.38^{\circ} 31^{\prime} \mathrm{W}\right)$, located in the Salvador municipality, Bahia State, Brazil. This zoo is located within an Atlantic Forest fragment, in a tropical to humid to super humid climate. The average annual precipitation is $1,758 \mathrm{~mm}$ and the average annual temperature is $25.3^{\circ} \mathrm{C}$ (INMET, 2016). The Zoo houses several primate species, including two Ateles paniscus individuals (one adult male and one adult female), which were the targets of this study. Faced with changes and technological advances, individual specimen data on their origin and date of incorporation into the PZGV stock are inaccurate. However, it is known that the individuals of $A$. paniscus were captive for more than 5 years in the park. The individuals were distinguished by their sex, age characteristics and face coloration. The spider monkeys were kept in a masonry enclosure measuring 21.84 x $4.60 \times 4.54 \mathrm{~m}$ (see Figure $1 \mathrm{~A}$ and $1 \mathrm{~B})$. This enclosure was divided into three 
FIGURE 1: Enclosure of Ateles paniscus in the Parque Zoobotânico Getúlio Vargas. A - Photograph and B - Illustration containing; 1 Sleeping area; 2 - Solarium, 3 - Contention/feeding area and their measures.
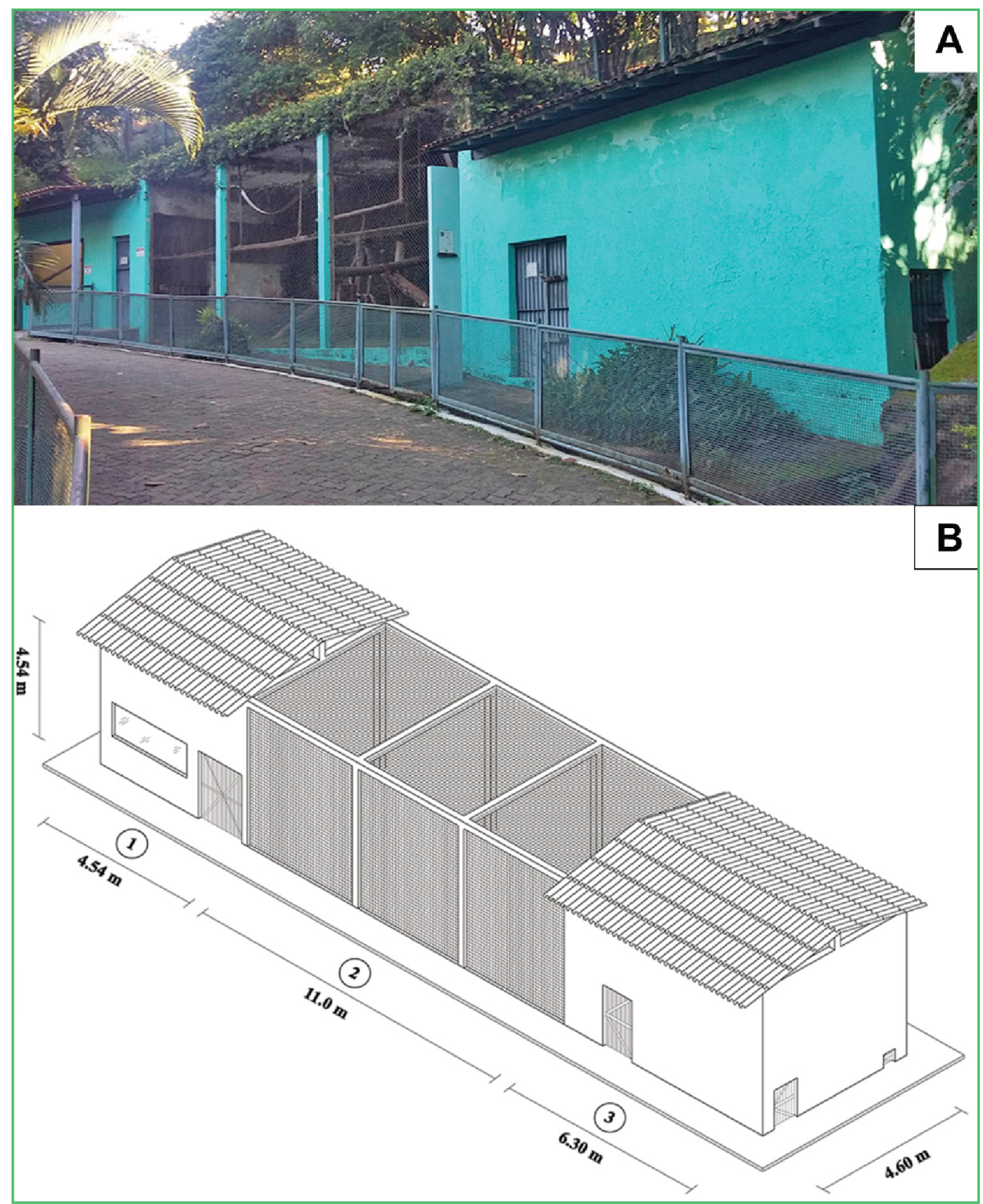

compartments: a sleeping area (where the individuals were led to sleep), a solarium (where the individuals stayed during the day) and a contention/feeding area (where the individuals were contained for veterinary procedures and cleaning, and where food was offered to them).

\section{Procedure}

This study was conducted between June 2011 and May 2012 and was divided into five phases: (i) control or pre-enrichment; (ii) sensory enrichment; (iii) social enrichment; (iv) feeding enrichment; and (v) postenrichment. The control phase consisted of observing the habitual behavioral patterns of the individuals without any type of enrichment in the enclosure. In 
the sensory enrichment phase, bamboo artifacts (30 $\mathrm{cm}$ ) containing odoriferous essences were constructed and inserted into different points of the enclosure to stimulate exploration of the environment. The essences consisted of parts of vegetables found adjacent to the enclosure, different from those inside, being periodically replaced and remaining in the enclosure during sensory phase. The main aim of the sensory enrichment was to encourage individuals to effectively explore the area of the enclosure through olfactory and visual stimuli, thus increasing frequency of movement while conditioned to a reduced captive environment. In the social enrichment phase, two adult females were introduced into the enclosure. This enrichment aimed to make the enclosure more dynamic and to provide greater social interaction between the individuals, considering that $A$. paniscus live in considerably large social groups (approximately 20 individuals; MITTERMEIER; VAN ROOSMALEN, 1981; VAN ROOSMALEN, 1985). In the food enrichment phase, a wood box $(50 \times 40 \mathrm{~cm})$ containing food items from their usual diet (leaves, fruits, and vegetables) was inserted into the enclosure to stimulate foraging. With feeding enrichment, we sought to vary how food is offered, making its acquisition more complex. The post-enrichment phase consisted of observing the behavior of the individuals without any type of enrichment in the enclosure. The aim of this phase was to verify the effectiveness of the proposed enrichments. The enrichments were developed based on the biology of the species, as suggested by Boere (2001), as well as the specificities of the enclosure, which can be a limiting factor to the enrichment proposal (e.g. limited space).

In order to mitigate the influence of the conditioning generated by the feeding time on the animal during the feeding enrichment phase, the method of "feeding break up" presented in Borges et al. (2011) was utilized. This consists of the supply of food items at different times and places so as to not allow for conditioning.

Preliminary observations were conducted to construct an ethogram for the study animals (Table 1).

TABLE 1: Ethogram for the observation of captive Ateles paniscus.

\begin{tabular}{ll}
\hline \multicolumn{1}{c}{ Behavior } & \multicolumn{1}{c}{ Description } \\
\hline Agonistic & $\begin{array}{l}\text { Demonstrate aggressive behavior with other individuals and may or may not come into } \\
\text { aggressive physical contact. }\end{array}$ \\
\hline Move & Shift on substrates or between substrates, without appearing to be engaged in any other activity. \\
\hline Play & $\begin{array}{l}\text { Making quick movements, jump, run, twist, bite, pull another individual's tail or chase; can be } \\
\text { solitary or social. }\end{array}$ \\
\hline Self-grooming & Grooming to remove parasites from their own fur using hands, tongue and/or teeth. \\
\hline Social grooming & $\begin{array}{l}\text { Grooming to remove parasites from the pelage of another individual (or to be groomed by it) } \\
\text { using the hands, tongue and/or teeth. }\end{array}$ \\
\hline Smell & Putting the nostrils close to something or someone and sniffing. \\
\hline Scratch & Scratching a body region with the hand, foot or using an object. \\
\hline Eat & Chewing or ingestion of food. \\
\hline Rest & No apparent dynamic activity; the individuals do not move. \\
\hline Stereotypy & Repetitive movements: pacing without apparent reason. \\
\hline Forage & Searching, catching and/or manipulating the food. \\
\hline Object manipulation & Handle the enrichment object inserted into the enclosure. \\
\hline Mark & Rubbing the pectoral or genital area on the substrate after smelling it or scratching it with teeth. \\
\hline Coprophagy & Chewing or ingestion of their own faeces or of another individual's faeces. \\
\hline Observe & Looking inattentive to any direction with no apparent purpose. \\
\hline Guard & Staring in a direction, the individual usually stands still, although it can move the trunk. \\
\hline Vocalize & Emitting long, high and loud sounds, typically for long distance communication. \\
\hline
\end{tabular}


We used the focal animal sampling method, with instantaneous observations of the individual's activity taken at 30-second intervals (ALTMANN, 1974). The observation periods consisted of one-hour sessions for each individual, divided into fifteen-minute subsections between the male and female for better behavioral representativeness; the sessions were conducted weekly between 8 a.m. and 2 p.m. At the end of the observation period, we had 360 records for each individual in each phase and 1,800 records in total.

\section{Statistical analysis}

All statistical analyses were based on the frequency of the male and female behavioral repertoires, treated separately. The behavioral repertoires observed during the enrichment phases were compared with the behaviors observed in the control phase with a Wilcoxon test; this test was chosen because the data were not normally distributed. We also verified whether there was a difference between the frequency of the manipulation of the object during the sensory and feeding phases with a Kruskal-Wallis test. The normality of the data was verified by a Shapiro-Wilk test. All analyses were conducted in BioEstat 5.0 (AYRES et al., 2007) at a significance level of 0.05 .

\section{Results}

In the preliminary phase, 16 behaviors were observed (Table 1). In the control phase, the female showed 11 of these behaviors: "observe" (35\%), "rest" $(22 \%)$ and "move" $(15 \%)$ were the behaviors with the highest frequencies (Figure 2). These behaviors were also relevant in the social enrichment phase, together with "play" $(12 \%)$, and in the sensory phase, in which they were complemented by "object manipulation" (9\%). During the feed enrichment phase, "observe" (44\%), "object manipulation" (20\%), and "move" (8\%) were the more common activities; "object manipulation" was more frequent (38\%) than in the sensory phase. In the post-enrichment phase, the most recorded acts were "observe" (53\%), "play" (16\%), "move" (12\%), and "scratch" (11\%).
The male showed 13 of the 16 behaviors in the control phase: "observe" (30\%), "rest" (26\%), and "move" (23\%) were the most frequent (Figure 3). These behaviors were also relevant in the social enrichment phase, together with "stereotypy" (11\%). In the sensory enrichment phase, "observe" (53\%), "rest" (17\%), and "stereotypy" (11\%) were the most frequent behaviors, although the latter maintained the same frequency as the social phase. "Observe" (61\%), "rest" (22\%), and "move" $(10 \%)$ were the most frequent behaviors in the feeding enrichment phase; in the post-enrichment phase, "observe" (56\%) and "stereotypy" (18\%) were the most frequent behaviors. Considering all phases, "observe", "rest", "move" and "stereotypy" were the most frequent behaviors.

The statistical tests showed significant differences between the frequencies of behaviors only during the feeding enrichment phase for the male (Table 2 ). The introduction of the objects in the enclosure during the sensory and feeding phases did not produce significant differences in behavior $(\mathrm{H}=3.4 ; p=0.18$; $\mathrm{GL}=2$ ).

TABLE 2: Wilcoxon test values and $p$-values from the comparisons among the enrichment phases.

\begin{tabular}{lcc}
\hline & Wilcoxon & $\boldsymbol{p}$-value \\
\hline Female & 39 & \\
Control x Social & 22 & 0.96 \\
Control x Sensory & 18 & 0.32 \\
Control x Feeding & 29 & 0.18 \\
Control x Post-enrichment & & \\
Male & 38 & 0.36 \\
Control x Social & 36 & 0.30 \\
Control x Sensory & 15 & 0.03 \\
Control x Feeding & 24 & 0.23 \\
Control x Post-enrichment & & \\
\hline
\end{tabular}


FIGURE 2: Frequencies of the behavioral acts of one female captive Ateles paniscus in different phases.

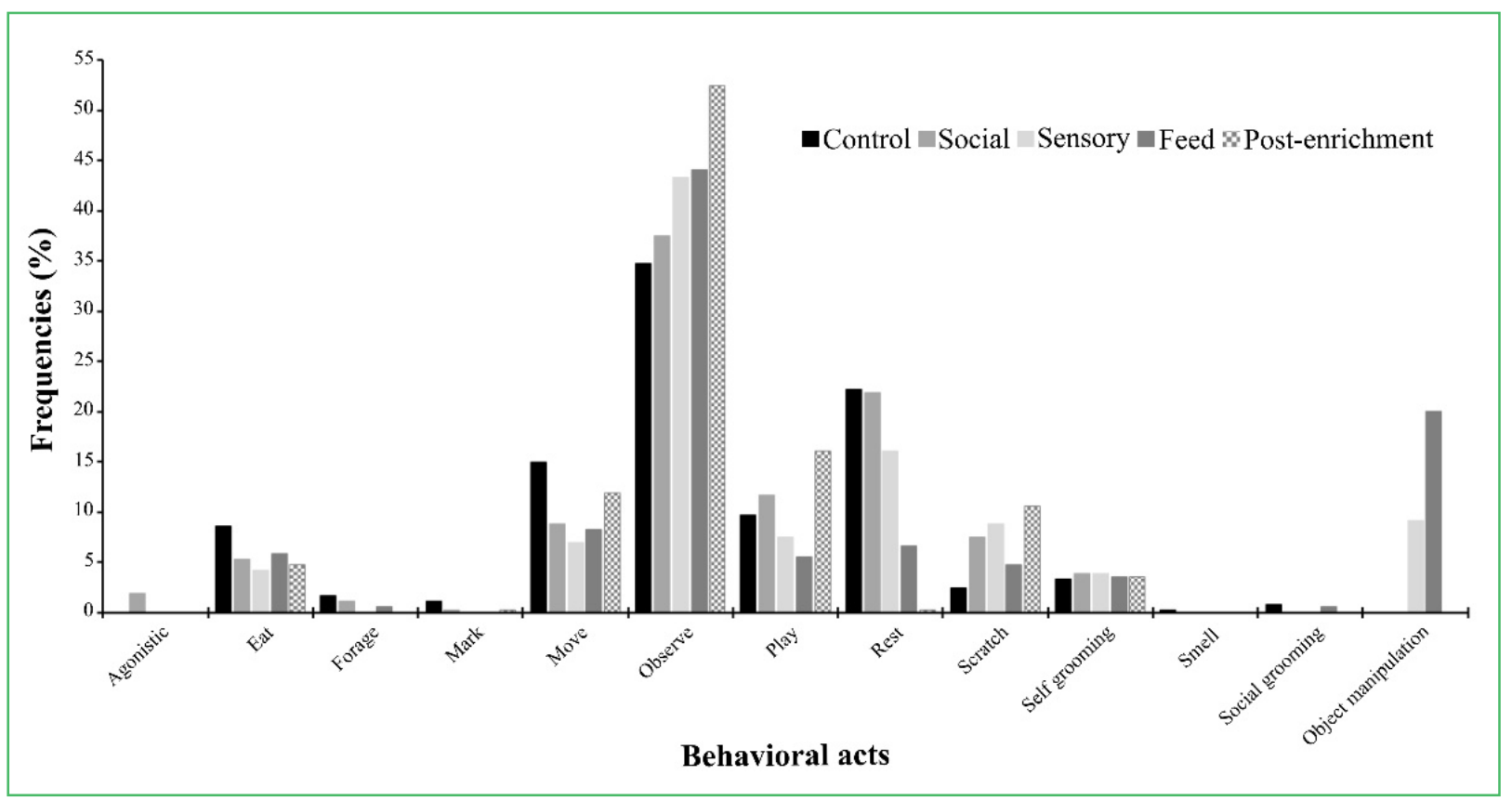

FIGURE 3: Frequencies of the behavioral acts of one male captive Ateles paniscus in different phases.

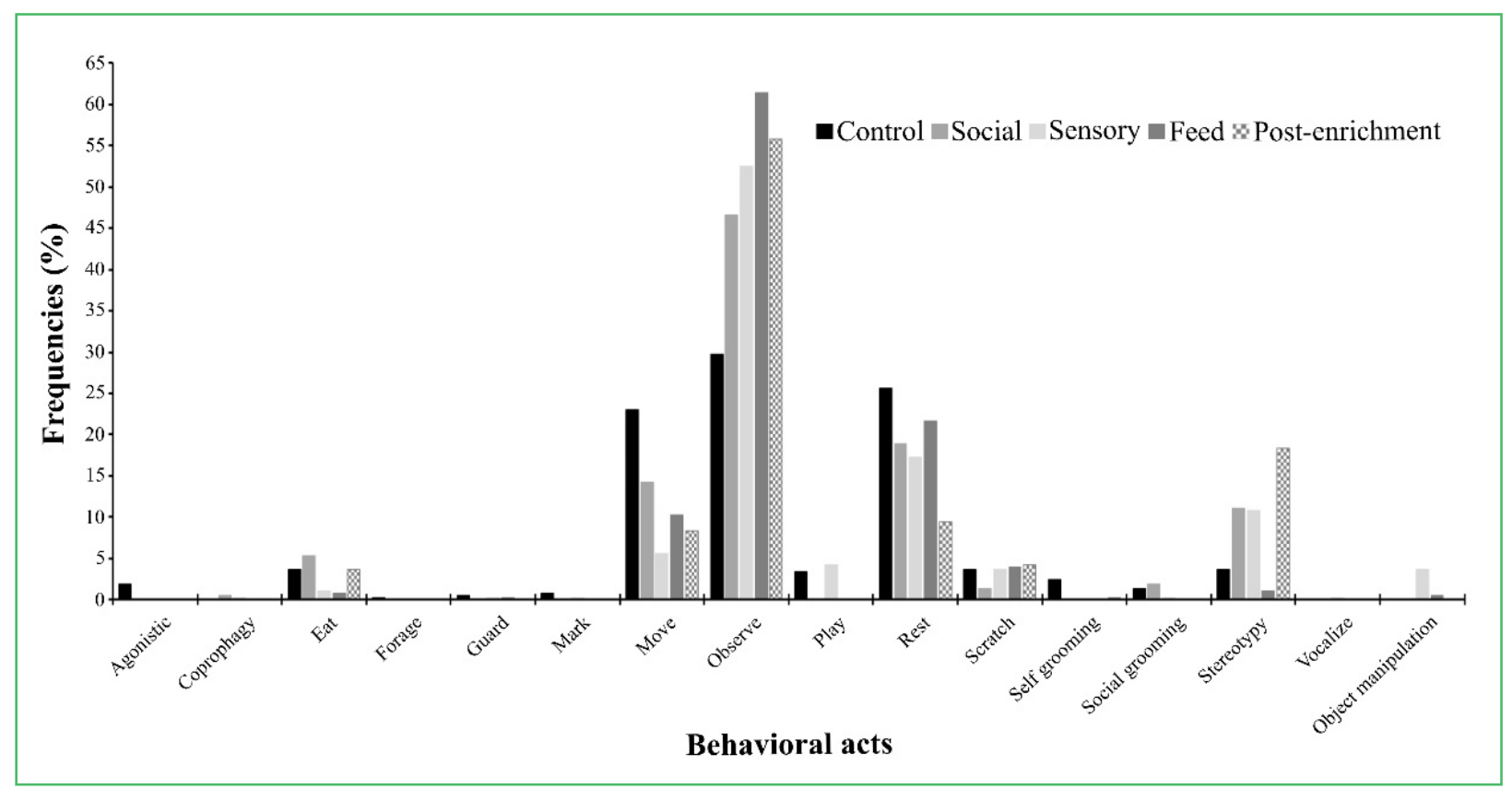




\section{Discussion}

Although there are many studies on the behavior of wild spider monkeys, few varieties of behavioral acts have been categorized for this group when compared to captive individuals. Perhaps this scenario is due to the greater ease that the captivity provides for the observation of these organisms. In general, the behaviors observed in wild spider monkeys can be grouped within three categories: "locomotion", "feeding", and "resting" (see MITTERMEIER; VAN ROOSMALEN, 1981; WHITE, 1986; SYMINGTON, 1988; YOULATOS, 2002). This limitation makes it difficult to compare our results with the behavioral repertoire of free-living individuals, since a longer list of activities are noted in captive individuals. However, it is important to highlight that the three behaviors most categorized in wild spider monkeys were also most frequently observed in our study.

"Observing", the most frequent behavior in this study, is not commonly reported for wild individuals; however, White (1986), when describing the behavior of Ateles paniscus chamek, included some inactive behaviors in the resting category, and it is possible that "observe" was one of these inactive behaviors. Other studies of captive spider monkeys (Ateles chamek, Ateles marginatus, and Ateles belzebuth in ALMEIDA et al., 2008 and Ateles fusciceps rifiventris in TORSTENSSON, 2009) did not report the "observe" behavior. However, in the current study, "observe" had a high frequency in all enrichment phases for both individuals, suggesting that the animals remained attentive to their environment.

"Rest" was the second most frequent behavior, decreasing in both individuals during the enrichment phases. Decreases in the frequency of "rest" during the enrichments are not consistent with observations in the natural environment. Resting behavior is more frequent in wild $A$. paniscus, with individuals spending up to half of their activity budget resting (SYMINGTON, 1988). Similar results to the present study were found by Torstensson (2009) with captive Ateles fusciceps rufiventris. Almeida et al. (2008) found different results for A. marginatus and A. belzebuth; in their study, the authors observed that "rest" and, social interactions were more frequent after the enrichments, and this was associated with a reduction in the high frequency of stereotyped behaviors expressed during the postenrichment phase.

The third most frequent behavior in our study, "move", also decreased with the use of enrichments, probably due to the greater occurrence of behavior such as "observe". "Move" is the least frequent act in wild Ateles, as demonstrated by White (1986) and Symington (1988). This information suggests the tendency of organisms in an enriched environment to present a behavioral similarity to free-living individuals. However, in the natural environment, $A$. paniscus has an extensive habitat area when compared to captive individuals, which have limited physical space. This does not allow us to make more precise discussions.

In general, our hypotheses about changes in the frequency of the behaviors acts due to enrichments were not supported. We expected that frequency of the stereotyped behavior would decrease and the frequency of the social and rest behaviors would increase compared to those in the control phase. However, the frequency of the stereotyped behavior increased whereas the frequency of the social and rest behaviors decreased (except for feeding enrichment for the male individual). Moreover, we expected that the artifact related to feeding enrichment would have a greater influence on the behavior of the individual since it presents an essential reward (food) when compared to the artifact of sensory enrichment. However, in this study, we did not observe any difference in the use of artifacts between the sensory and feeding enrichment. Based on this result, we conclude that $A$. paniscus individuals have similar interest in the artifacts used in different types of enrichment.

In relation to stereotyped behavior (observed only in the adult male), it is worth highlighting that this behavior was previously reported in another study of Ateles, being associated mainly to pre-feeding stress (ALMEIDA et al., 2008). Perhaps the enrichments used in our study were not adequate to eliminate stereotypy, although this kind of behavior varied with the different enrichments, as also occurred in Almeida et al. (2008). However, the male individual showed this behavior 
mainly in the presence of visitors. It is possible that the presence of visitors exerted a negative effect on the behavior of captive $A$. paniscus in the PZGV since when visitation stopped or became reduced, the behaviors also stopped (personal observation). This situation has been previously reported in other studies, which observed a negative influence of zoo visitors on captive animals, mainly primates (CHAMOVE et al., 1988; SADE, 2013; SHERWEN; HEMSWORTH, 2019). We emphasize that studies considering this possible interference is necessary in the PZGV. Nevertheless, we cannot rule out the possibility that enrichments acted as stressors. Pizzutto et al. (2008) reported the negative effect of environmental enrichments on other captive nonhuman primates.

The usual way of food offering for the Ateles of PZGV at the ground level may also have caused a negative influence on their behavior. In nature, South American spider monkeys feed in the higher strata of the forest and rarely come down to the forest floor. This behavior is different from those observed in Central American spider monkeys, perhaps due to differences in the food availability and predators in these regions (MITTERMEIER, 1978; MITTERMEIER; VAN ROOSMALEN, 1981; VAN ROOSMALEN, 1985; YOULATOS, 2002; CAMPBELL et al., 2005). Torstensson (2009) evaluated the efficacy of using trees for the food offering for captive A. fusciceps rufiventris (Sclater, 1872) and found satisfactory results in relation to increasing the individuals' welfare. Such considerations suggest the need to change the structure of the enclosure and how food is offered to the individuals of Ateles in the PZGV since the enclosure presents a low ceiling and does not have large trees that resemble those found in the natural environment.

Moreover, the conditions of Ateles' captive environment in the PZGV were not favorable for social interactions, since two individuals shared the enclosure. Wild A. paniscus live in considerably large groups with adult males and females, juveniles, and infants (VAN ROOSMALEN, 1985); intra- and inter-specific interactions are frequent (MITTERMEIER; VAN ROOSMALEN, 1981; VAN ROOSMALEN, 1985; WHITE, 1986; SYMINGTON, 1988; CAMPBELL et al., 2005), suggesting the potential importance of social enrichment for this species, as demonstrated in the social enrichment phase.

Although no significant changes were observed in the behavioral repertoire of individuals from $A$. paniscus, the results showed the influence of an enriched environment on the frequency of the individuals' behavioral acts. It is likely that the conditions of the enclosure and the flow of visitors had negative impacts on enrichment, preventing the elimination of abnormal behavior. Thus, to minimize the impacts of the captive environment and better understand the effects of enrichment on the species, other measures should be adopted, such as the expansion and restructuring of the physical space, the insertion of a tall fruitful tree, and other modifications that would satisfy the needs and specificities of the species. We emphasize that for A. paniscus individuals kept in PZGV, it is necessary to minimize the influence of visitors on the animals, to change the form and location of the food offered and to implement mechanisms that facilitate the incorporation of new individuals into the enclosure.

\section{Acknowledgements}

We thank the Parque Zoobotânico Getúlio Vargas administrators for allowing the execution of the activities presented here and for logistic support; to the employees of the PZGV, particularly to Mr. Erivaldo Silva; to Dilson Magalhães for the illustrating the enclosure and to Arielson Protázio for the valuable help. We also thank to two anonymous referees for valuable comments on our manuscript.

\section{References}

ALMEIDA, A. M. R.; MARGARIDO, T. C. C.; FILHO, E. L. D. A. M. Influência do enriquecimento ambiental no comportamento de primatas do gênero Ateles em Cativeiro. Arquivos de Ciências Veterinárias e Zoologia da Unipar, Umuarama, v. 11, n. 2, p. 97 $102,2008$.

ALTMANN, J. Observational study of behavior: sampling methods. Behaviour, Atlanta, v. 49, p. 227-267, 1974.

AYRES, M.; AYRES JÚNIOR, M.; AYRES, D. L.; SANTOS, A. A. BIOESTAT 5.0 - Aplicações estatísticas nas áreas das ciências biomédicas. Belém: Ong. Mamirauá, 2007. 364 p. 
AZEVEDO, C. S.; BARÇANTE, L. Enriquecimento ambiental em zoológicos brasileiros: em busca do bem-estar animal. Revista Brasileira de Zoociências, Juiz de Fora, v. 19, n. 2, p. 15-34, 2018. BLOOMSMITH, M. A.; BRENT, L. Y.; SCHAPIRO, S. J. Guidelines for developing and managing an environmental enrichment program for nonhuman Primates. Laboratory Animal Science, Cordova, v. 41, n. 4, p. 372-377, 1991.

BOERE, V. Environmental enrichment for neotropical primates in captivity. Ciência Rural, Santa Maria, v. 31, n. 3, p. 543-551. 2001.

BORGES, M. P.; BYK, J.; DEL-CLARO, K. Influência de técnicas de enriquecimento ambiental no aumento do bem-estar de Callithrix penicillata (E. Geoffroy, 1812) (Primates: Callitrichidae). Biotemas, Florianópolis, v. 24, n. 1, p. 83-94, 2011.

BROOM, D. M. Indicators of poor welfare. British Veterinary Journal, London, v. 142, p. 524-526. 1986.

BROOM, D. M. Animal welfare: concepts and measurement. Journal of Animal Science, Champaign, v. 69, p. 4167-4175, 1991. BUCHANAN-SMITH, H. M. Environmental enrichment for primates in laboratories. Advances in Science \& Research, Göttingen, v. 5, p. 41-56, 2010.

CAMPBELL, C. J.; AURELI, F.; CHAPMAN, C. A.; RAMOSFERNÁNDEZ, G.; MATTHEWS, K.; RUSSO, S. E.; SUAREZ, S.; VICK, L. Terrestrial behavior of Ateles spp. International Journal of Primatology, New York, v. 26, n. 5, p. 1039-1051, 2005.

CARLSTEAD, K.; SHEPHERDSON, D. Effects of environmental enrichment on reproduction. Zoo Biology, New York, v. 13, p. 447458, 1994.

CHAMOVE, A.; HOSEY, G.; SCHAETZEL, P. Visitors excite primates in zoos. Zoo Biology, New York, v. 7, p. 359-369, 1988.

CHAPMAN, C. A.; CHAPMAN, L. J. Reproductive biology of captive and free-ranging spider monkeys. Zoo Biology, New York, v. 9, p. 1-9, 1990.

ETIM, N. N.; OfFIONG, E. E. A.; EYOH, G. D.; UDO, M. D. Stress and animal welfare: an uneasy relationship. European Journal of Advanced Research in Biological and Life Sciences, Birmingham, v. 1, n. 1, p. 9-16, 2013.

INMET - INSTITUTO NACIONAL DE METEOROLOGIA. 2016 Brasil. Disponível em: < http://www.inmet.gov.br/portal/>.

IUCN. Red list of threatened species. Cambridge: International Union of Conservation of Nature and Natural Resources. 2020. Disponível em: $<$ http://www.iucnredlist.org/details/2283/0>.

JWGR - JOINT WORKING GROUP ON REFINEMENT. Refinements in husbandry, care and common procedures for non-human primates: 9th report of the BVAAWF/FRAME/ RSPCA/UFAW JointWorking Group on Refinement (M Jennings \& MJ Prescott, eds). Laboratory Animals, London, v. 43 (Suppl 1), p. 1-47, 2009.

KELLOGG, R.; GOLDMAN, E. A. Review of the spider monkeys. Proceedings of the United States National Museum, Washington, v. 96, n. 3186, p. 1-45, 1944.

KONSTANT, W.; MITTERMEIER, R. A.; NASH, S. D. Spider monkeys in captivity and in the wild. Primate Conservation, Washington, v. 5, p. 82-109, 1985.
LAUTON, D. C. R.; COSTA NETO, A. O. Efeito de técnicas de enriquecimento ambiental no comportamento de Leontopithecus chrysomelas (Kuhl, 1820) (Primates: Callitrichidae). Pesquisa e Ensino em Ciências Exatas e da Natureza, Cajazeiras, v. 2, n. 2, p. 86-94, 2018.

LAUTON, D. C. R.; PROTÁZIO, A. S.; LIMA, J. S. S.; OLIVEIRA, T. V. Influência de técnicas de enriquecimento ambiental no comportamento de Alouatta caraya (Humboldt, 1812) (Primates: Atelidae) cativos no Parque Zoobotânico Getúlio Vargas, Salvador, Bahia. In: RUIZ, V. R. R. (Org.). Comportamento Animal. Curitiba: Atena Editora, 2019. p. 64-75.

MANACERO, R. B.; TANDELlO, A. M.; NOGALI, O. Enriquecimento ambiental como ferramenta de tratamento para redução de comportamento estereotipado de macaco-caiarara (Cebus kaapori). Atas de Saúde Ambiental, São Paulo, v. 2, n. 2 , p. 47-53, 2014.

MITTERMEIER, R. A. Locomotion and posture in Ateles geoffroyi and Ateles paniscus. Folia Primatologica, Basel, v. 30, p. 161-193, 1978.

MITTERMEIER, R. A.; VAN ROOSMALEN, M. G. M. Preliminary observations on habitat utilization and diet in eight Surinam monkeys. Folia Primatologica, Basel, v. 36, p. 1-39, 1981.

NEWBERRY, R. C. Environmental enrichment: increasing the biological relevance of captive environments. Applied Animal Behaviour Science, Amsterdam, v. 44, p. 229-243, 1995.

PIZZUTTO, C. S.; SGAI, M. G. F. G.; VIAU, P.; CHELINI, M. O. M.; OLIVEIRA, C. A.; GUIMARÃES, M. A. B. V. Validação laboratorial e fisiológica de conjunto comercial para a quantificação de corticoides fecais em chimpanzé (Pan troglodytes) e orangotango (Pongo pygmaeus), cativos e submetidos a enriquecimentos ambientais. Brazilian Journal of Veterinary Research Animal Science, São Paulo, v. 45, p. 104-110, 2008.

PORTO, G. S.; LIMA, I. P.; REIS, N. R.; PERACCHI, A. L.; ROSA, G. L. M. Subfamília Atelinae - gênero Ateles (É. Geoffroy, 1806). In: REIS, N. R.; PERACCHI, A. L.; BATISTA, C. B; ROSA, G. L. M. (Org.). Primatas do Brasil: guia de campo. Rio de Janeiro: Technical Books, 2015. p. 279-287.

RAMPIM, L. V.; OLIVA, V. N. L. S. Benefits of environmental enrichment in animal welfare: a literary review. Revista de Ciência Veterinária e Saúde Pública, Umuarama, v. 3, n. 1, p. 60-66, 2016. RANGEL-NEGRÍN, A.; ALFARO, J. L.; VALDEZ, R. A.; ROMANO, M. C.; SERIO-SILVA, J. C. Stress in Yucatan spider monkeys: effects of environmental conditions on fecal cortisol levels in wild and captive populations. Animal Conservation, London, v. 12, p. 496-502, 2009.

SADE, C. Visitor effects on zoo animals. The Plymouth Student Scientist, Plymouth, v. 6, n. 1, p. 423-433, 2013.

SHERWEN, S. L.; HEMSWORTH, P. H. The visitor effect on zoo animals: implications and opportunities for zoo animal welfare. Animals, Basel, v. 9, n. 366, p. 1-27, 2019.

SHEPHERDSON, D. Principles of and research on environmental enrichment for mammals. In: KLEIMAN, D. G.; THOMPSON, K. V.; BAER, C. K. (Ed.). Wild mammals in captivity: principles and techniques for zoo management. Chicago: University of Chicago Press, 2010. p. 62-67. 
SOARES-FILHO, B. S.; NEPSTAD, D. C.; CURRAN, L. M.; CERQUEIRA, G. C.; GARCIA, R. A.; RAMOS, C. A.; VOLL, E.; MCDONALD, A.; LEFEBVRE, P.; SCHLESINGER, P. Modeling conservation in Brazilian Amazonia. Nature, London, v. 440, p. 520-523, 2006.

SOBROZA, T. V.; FORTES, V. B. Environmental enrichment for captive capuchin monkeys (Sapajus spp.) using natural material. Revista Brasileira de Zoociências, Juiz de Fora, v. 19, n. 2, p. 47-58, 2018.

SYMINGTON, M. M. Demography, ranging patterns, and activity budgets of black spider monkeys (Ateles paniscus chamek) in the Manu National Park, Peru. American Journal of Primatology, New York, v. 15, p. 45-67, 1988.

TAKAHASHI, J. A literature review of the spider monkey, Ateles sp, with special focus on risk for extinction. Uppsala: Swedish University of Agricultural Sciences, 2008. 27 p.
TORSTENSSON, T. Enrichment for Colombian black spider monkeys (Ateles fusciceps rufiventris) in a zoo. Skara: Swedish University of Agricultural Sciences, 2009. 28 p.

VAN ROOSMALEN, M. G. M. Habitat preferences, diet, feeding strategy and social organization of the black spider monkey (Ateles paniscus paniscus Linnaeus, 1758) in Surinam. Acta Amazonica, Manaus, v. 15, n. 3/4, p. 1-238, 1985.

VOLPATO, G. L.; GIAQUINTO, P. C.; CASTILHO, M. F.; BARRETO, R. E.; FREITAS, E. G. Animal welfare: from concepts to reality. Oecologia Brasiliensis, Rio de Janeiro, v. 13, n. 1, p. 5-15, 2009.

WHITE, F. Census and preliminary observations on the ecology of the black-faced black spider monkey (Ateles paniscus chamek) in Manu National Park, Peru. American Journal of Primatology, New York, v. 11, p. 125-132, 1986.

YOULATOS, D. Positional behavior of black spider monkeys (Ateles paniscus) in French Guiana. International Journal of Primatology, New York, v. 23, n. 5, p. 1071-1093, 2002. 